\title{
Longitudinal clinicopathological follow up of breast cancer patients from 1988 to 1996 in Jakarta
}

\author{
Didid Tjindarbumi*, Gunawan Tjahjadi\#, Muchlis Ramli*, Yoshiyuki Ohno ${ }^{\dagger}$, Idral Darwis*, \\ Goi Sakamoto ${ }^{*}$, Santoso Cornain ${ }^{\#}$, Esti Soetrisno\#, Joedo Prihartono ${ }^{\circ}$, Endang Sri Roostini", \\ Setyawati Budiningsih ${ }^{\circ}$, Kenji Wakai ${ }^{\dagger}$, Drupadi S Dillon\$
}

\begin{abstract}
Abstrak
Kanker payudara merupakan keganasan yang paling sering ditemukan pada wanita Indonesia sesudah kanker mulut rahim. Sejak tahun 1988 dmulai kerjasama penelitian tentang etiologi dan klinikopatologi kanker payudara, antara pemerintah Jepang dan Indonesia. Penelitian ini dibagi dalam 2 fase. Pada fase I (1988 s'd 1992) diteliti 300 kasus kanker payudara baru dan dibandingkan dengan 600 kasus kontrol. Pada fase II (1993 s/d 1996) diteliti 266 kasus kanker payudara baru den dibandingkan dengan 452 kontrol. Makalah ini akan membicarakan ketahanan dan harapan hidup 5 tahun dari 110 penderita kanker payudara operabel yang termasuk kelompok I dilihat dari segi klinikopatologi. Sisa 190 dari jumlah 300 kasus yang termasuk kelompok I itu, tidak diikut sertakan karena sudah berada dalam keadaan lanjut dan buruk, dan tidak memungkinkan untuk mendapatkan pengobatan lengkap. Kasus kanker payudara operabel yang ternasuk fase II, 75 kasus, juga tidak diikutsertakan karena masa observasi 5 tahun selurulnya baru akan selesai tahun 2001. Diantara 110 kasus kanker payudara operabel yang dioperasi dari tahun 1989, 1992 dan diikuti s/d 1996, ditemukan 43 (39\%) penderita meninggal di rumah sakit atau rumah sendiri, 33 (30\%) masih hidup tanpa adanya penyebaran atau kekambuhan penyakit dan 34 (3I\%) masih hidup, tapi sudah ada kekambuhan/penyebaran penyakit. Analisa ketahanan hidup 5 tahun dari seluruh 110 penderita kanker payudara adalah: $68,8 \%$ dengan perincian $87,5 \%$ dari Stadium I, 61,3\% dari Stadium II dan 57,8\% dari Stadium IIIA.
\end{abstract}

\begin{abstract}
Breast cancer belongs to the leading cancer among Indonesian women, it ranked second to the cancer of the utterine cervix. A collaborative study on the etiology and clinicopathology of breast cancer between Japan and Indonesia has been carried out. This study was started in 1988 and conducted in 2 batches. The first was between 1988-1992, where 300 cases and 600 controls were studied, which was extended with the second bach from 1992-1996, for further nutritional analysis on 226 and 452 controls. This paper will discuss the 5 year longitudinal clinicopathological follow up observation on 110 operable cases belonging 10 the 300 lst batch patients. The remaining 190 patients were late cases and were not suitable for this project since many of them were in a worse condition. The operable patiens (75) from the $2^{\text {nd }}$ batch (226) were not included since the 5 year survival analysis would not be done until the year 2001 . Among 110 operable breast cancer admitted between 1989 through 1992, we found 43 (39\%) patients died in the hospital or at their own home, $33(30 \%)$ patients are alive without recurrence and $34(31 \%)$ patients are alive, but with recurrence or metastatic disease. The overall 5 year survival rate was 68.8\% with the following details: $87.5 \%$ from Stage 1, 61.3\% from Stage II and 57.8\% from Stage IIIA.
\end{abstract}

Keywords: Breast cancer, operable cases, longitudinal study, clinicopathological, survival analysis.

\section{INTRODUCTION}

Breast cancer presents an enormous public health problem in countries with a high as well as low social socio-economic level.l The morbidity rate and the

* Department of Surgery, Faculty of Medicine, University of Indonesia, Jakarta 10430, Indonesia

\# Department of Anatomic Pathology, Faculty of Medicine, University of Indonesia, Jakarta 10430, Indonesia

+ Department of Preventif Medicine, Nagoya University School of Medicine, Nagoya 466, Japan

- Department of Pathology, Cancer Institute, Tokyo 170, Japan

- Department of Community Medicine, Faculty of Medicine, University of Indonesia, Jakarta 10320, Indonesia

$\$$ Department of Nutrition. Faculty of Medicine, University of Indonesia, Jakarta 10430, Indonesia mortality rate remain difficult to control despite of the therapeutic advances combined modality of surgery, radiotherapy and chemotherapy.

This cancer is fairly common in Indonesia, varying from $10 \%$ to $11,5 \%$ of all the malignant lesions in the females. 2,3 In females it is the second most frequent tumor after cervical carcinoma with relative frequency (age standardized cancer ratio) of $18,41 \%$ of all female malignancies in 1989. The prognosis has been considered poor with about 50\% 5-years relative survival and a $15-20 \%$ overall long-term relative survival.4-6 It is of interest to study the five year survival of Indonesian breast cancer patients in conjunction with clinical staging, type of operation, histopathological findings and risks factors such as age, 
menarche, menstrual status, marital status, number of children, and cancer history in the family.

For this purpose 2 batches of case control studies were conducted between 1988-1996 at the Department of Surgery Dr. Cipto Mangunkusumo Teaching Hospital/Medical School University of Indonesia, Jakarta. These studies were a collaborative research between the Faculty of Medicine University of Indonesia, Jakarta, Indonesia and Nagoya City University, Nagoya University School of Medicine, Nagoya and the Cancer Institute, Tokyo, Japan.

\section{MATERIALS AND METHODS}

The 1 st batch consisted of 300 cases newly diagnosed breast cancer patients admitted for treatment during the period of 1989 until 1992 and followed up until December 1996. The $2^{\text {nd }}$ batch consisted of 226 cases that were admitted between 1993 until 1996 but will not be included in this paper since the 5 years survival analysis would not be done until the year 2001 . Of the 300 patients belonging to this research project, only 110 operable patients were subjected to the 5 years follow up observation. The remaining 190 cases were in late stages and were not suitable for this project since many of them died several weeks after their first admittance in the Hospital due to worse condition. All needed information related to the known etiological factors were carefully recorded. All the cases were clinically examined and subjected to routine laboratory examination. Other investigations such as chest X-ray, skeletal X-ray and liver function test were also carried out in most cases.

In all cases histopathological typing according to modified classification recommended by the Japanese Breast Cancer Society ${ }^{7}$ was done and for clinical staging the International TNM classification was applied. 8 All operable patients were treated by surgery like simple mastectomy, radical mastectomy and modified radical mastectomy, radiotherapy in combination with surgery. Chemotherapy in combination with surgery and radiotherapy as adjuvant therapy according to Breast Cancer Management Protocol of the Indonesian Surgical Oncology Association (renewed in July 1989). ${ }^{1}$ The survival curve was analyzed according to Kaplan-Meier method. ${ }^{9}$

\section{RESULTS}

The age distribution of 110 operable breast cancer cases is given in Table 1 and that related to the clinical stage is given in Table 2. Relatively high propor- tion of cases was already seen in younger age group namely at $35-39$ yrs. The majority, $64.5 \%$ were of stage IIIA and $28.2 \%$ of stage II and only $7.3 \%$ were of stage I.

Table 1. Age incidence of 110 operable female breast cancer

\begin{tabular}{ccc}
\hline Age in years & Cases & $\%$ \\
\hline$<35$ & 12 & 10.9 \\
$35-39$ & 23 & 20.9 \\
$40-44$ & 22 & 20.0 \\
$45-49$ & 21 & 19.0 \\
$50-54$ & 13 & 12.0 \\
$55-59$ & 15 & 13.6 \\
$60-65$ & 4 & 3.6 \\
\hline Total & 110 & 100.0 \\
\hline
\end{tabular}

Table 2. Clinical stages of operable breast cancer cases at admission

\begin{tabular}{|c|c|c|c|c|c|c|}
\hline \multicolumn{4}{|c|}{ Stage } & \multirow{2}{*}{$\begin{array}{c}\text { Cases } \\
4\end{array}$} & \multirow[t]{2}{*}{ Total } & \multirow[t]{2}{*}{$\%$} \\
\hline 1 & $T_{1 i}$ & $\mathrm{~N}_{0}$ & $\mathrm{M}_{0}$ & & & \\
\hline & $\mathrm{T}_{\mathrm{lb}}$ & $\mathrm{N}_{\mathrm{li}}$ & $\mathrm{M}_{0}$ & 4 & 8 & 7.32 \\
\hline \multirow[t]{5}{*}{ II } & $\mathrm{T}_{2 \mathrm{a}}$ & $\mathrm{N}_{0}$ & $\mathrm{M}_{0}$ & 6 & & \\
\hline & $\mathrm{T}_{2 \mathrm{~b}}$ & $\mathrm{~N}_{0}$ & $M_{0}$ & 4 & & \\
\hline & $\mathrm{T}_{2 \mathrm{u}}$ & $\mathrm{N}_{\mathrm{lu}}$ & $M_{0}$ & 12 & 31 & 28.2 \\
\hline & $\mathrm{T}_{2 \mathrm{~b}}$ & $\mathrm{~N}_{\text {li }}$ & $M_{n}$ & 2 & & \\
\hline & $\mathrm{T}_{2 \mathrm{c}}$ & $\mathrm{N}_{\mathrm{lb}}$ & $\mathrm{M}_{0}$ & 7 & & \\
\hline \multirow[t]{6}{*}{ IIIA } & $\mathrm{T}_{3: 1}$ & $\mathrm{~N}_{0}$ & $M_{0}$ & 33 & & \\
\hline & $\mathrm{T}_{3 \mathrm{i}}$ & $\mathrm{N}_{\text {lia }}$ & $M_{0}$ & 32 & & \\
\hline & $\mathrm{T}_{3: 1}$ & $N_{1 b}$ & $M_{0}$ & 3 & & \\
\hline & $\mathrm{T}_{4 \mathrm{il}}$ & $\mathrm{N}_{0}$ & $\mathrm{M}_{0}$ & 1 & 71 & 64.5 \\
\hline & $\mathrm{T}_{4 \mathrm{a}}$ & $\mathrm{N}_{\mathrm{lb}}$ & $\mathrm{M}_{0}$ & 2 & & \\
\hline & $\mathrm{T}_{4 \mathrm{u}}$ & $\mathrm{N}_{2}$ & $\mathrm{M}_{0}$ & 2 & & \\
\hline Total & & & & 110 & 110 & 100.0 \\
\hline
\end{tabular}

The site of the tumor was mostly found in the upper outer quadrant $(70.9 \%)$, followed by upper inner quadrant $(16.4 \%)$, lower inner quadrant $(7.3 \%)$, subareolar $(3.6 \%)$ and lower outer quadrant $(1.8 \%)$. See Table 3.

Table 3. Distribution of operable breast cancer cases according to site of involvement

\begin{tabular}{lcr}
\hline \multicolumn{1}{c}{ Site } & Cases & \multicolumn{1}{c}{$\%$} \\
\hline Upper outer quadrant & 78 & 70.9 \\
Lower outer quadrant & 2 & 1.8 \\
Upper inner quadrant & 18 & 16.4 \\
Lower inner quadrant & 8 & 7.3 \\
Subareolar & 4 & 3.6 \\
\hline Total & 110 & 100.0 \\
\hline
\end{tabular}


The proportion of cases underwent each type of surgery are listed in Table 4 . Simple mastectomy was performed on two third of the cases. Radical mastectomy, modified radical mastectomy and breast conserving treatment were performed in $21.0 \%, 11.8 \%$ and $1.89 \%$ of cases respectively.

Table 4. Distribution of operable breast cancer cases according to type of surgery

\begin{tabular}{lcr}
\hline Type of surgery & Cases & $\%$ \\
\hline Radical Mastectomy & 23 & 21.0 \\
Modified Radical Mastectomy & 13 & 11.8 \\
Simple Mastectomy & 72 & 65.4 \\
Breast Canserving Treatment (BCT) & 2 & 1.8 \\
\hline Total & 110 & 100.0 \\
\hline
\end{tabular}

Further clinicopathological data with regards to lymph node involvement are given in Table 5. Lymph node involvement was found in 14 cases with stage II. Negative lymph nodes were found in 8 cases with stage I and in 16 cases with stage II. Their relationship to different surgical procedures are shown in the Table.

From the total hospital admissions for operable breast cancer from 1989 to 1992, 43 (39\%) patients died in the hospital and at their own home, $33(30 \%)$ patients were alive without recurrence and $34(31 \%)$ patients were alive but with recurrence or metastatic disease. In this context, the disease free interval was analyzed in relation to the stage of the disease as shown in Table 6 and Table 7 .

Table 5. Distribution of operable breast cancer cases according to type of surgery, clinical stage and involvement of the regional lymph nodes

\begin{tabular}{lcccc}
\hline Type of surgery & Stage & Cases & $\begin{array}{c}\text { Lymph node involvement (+) } \\
\text { metastasis }\end{array}$ & $\begin{array}{c}\text { Lymph node involvement (-) } \\
\text { metastasis }\end{array}$ \\
\hline Radical mastectomy & I & 8 & $(-)$ & 8 \\
Modified Radical mastectomy & II & 15 & 7 & 6 \\
Breast Conserving therapy & II & 13 & 1 & 7 \\
\hline
\end{tabular}

The number of the average dissected lymph nodes were 6.8 lymph nodes

Table 6. Type of surgery performed and other Modes of therapy adopted for operable breast cancer patients

\begin{tabular}{lccll}
\hline Surgery performed & Cases & Stage & Adjuvant therapy & Follow up \\
\hline Radical mastectomy & 14 & I \& II & None & Good response complete follow up \\
& 9 & II & Radiotherapy \\
Rodified Radical mastectomy & 13 & II & Radiotherapy & $\begin{array}{l}\text { Good response } \\
\text { Recurrences in some, }\end{array}$ \\
Simple mastectomy & 72 & IIIA & $\begin{array}{l}\text { Radiotherapy + Chemotherapy } \\
\text { some did not complete } \\
\text { the course of chemotherapy }\end{array}$ & $\begin{array}{l}\text { Recurrences in some, } \\
\text { 40 died of distant metastasis }\end{array}$ \\
Breast Conserving Treatment & 2 & I +II & Radiotherapy & Skin recurrences in one patient \\
\hline Total & 110 & & &
\end{tabular}


Table 7. Five years follow up of 110 operable breast cancer patients from the Dr. Cipto Mangunkusumo (1989-1992), comparing survival status in relation to various demographic data and surgery

\begin{tabular}{|c|c|c|c|c|}
\hline & Alive with Recurrence & Alive without Recurrence & Deceased & Total \\
\hline \multicolumn{5}{|l|}{ Age group: } \\
\hline $10-29$ & 0 & 1 & 5 & 6 \\
\hline $30-39$ & 8 & 9 & 10 & 27 \\
\hline $40-49$ & 10 & 19 & 11 & 40 \\
\hline $50-59$ & 13 & 3 & 14 & 30 \\
\hline 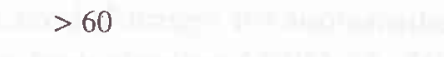 & 3 & 1 & 3 & 7 \\
\hline \multicolumn{5}{|l|}{ Age at menarche: } \\
\hline$<12$ & 0 & 1 & 0 & 1 \\
\hline $12-15$ & 22 & - & 40 & 82 \\
\hline 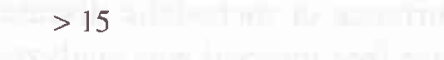 & 12 & 13 & 3 & 27 \\
\hline \multicolumn{5}{|l|}{ Menstrual status: } \\
\hline Regular & 8 & 29 & 20 & 57 \\
\hline Irregular & 6 & 4 & 0 & 10 \\
\hline Menopause & 20 & 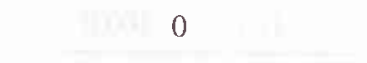 & 23 & 43 \\
\hline \multicolumn{5}{|l|}{ Marital status: } \\
\hline Married & 30 & 31 & 43 & 104 \\
\hline Non Married & 4 & 2 & 0 & 6 \\
\hline \multicolumn{5}{|l|}{ Number of children: } \\
\hline$(0)$ & 0 & 3 & 7 & 10 \\
\hline$(+)$ & 34 & 30 & 36 & 100 \\
\hline \multicolumn{5}{|l|}{ History of cancer: } \\
\hline$(+)$ & 3 & 2 & 38 & 43 \\
\hline$(-)$ & 31 & 31 & 5 & 67 \\
\hline \multicolumn{5}{|l|}{ Clinical stage: } \\
\hline I & 0 & 7 & 1 & 8 \\
\hline II & 6 & 13 & 12 & 31 \\
\hline IIIa & 28 & 13 & 30 & 71 \\
\hline \multicolumn{5}{|l|}{ Surgical procedure: } \\
\hline Modified Radical Mastectomy & 2 & 2 & 9 & 13 \\
\hline Radical Mastectomy & 12 & 7 & 4 & 23 \\
\hline Simple Mastectomy & 19 & 23 & 30 & 72 \\
\hline Breast Conserving Treatment & 1 & 1 & - & 2 \\
\hline
\end{tabular}

Of the 8 patients with stage I, $7(8.5 \%)$ were still alive without recurrence, $1(12.5 \%)$ died not caused by cancer but got heart attack in the hospital. In stage II, out of 31 patients, $13(42 \%)$ were at present disease free, $6(19.3 \%)$ had developed recurrent disease within 4-5 years follow up and $12(38.7 \%)$ died of distant metastasis. In stage III, out of 71 patients only $13(18,3 \%)$ were disease free, $28(39.4 \%)$ had developed recurrent or metastatic disease within 4 years or less and $30(42.2 \%)$ patients died of distant metastasis.
All 110 patients of breast cancer cases were female. The age incidence is shown in Table 7. The youngest patient was a 22-year old married woman and the oldest was a female of 63 years. Between these extremes, we found that more than half $(68.18 \%)$ of the cases were at age above 40 . The maximum incidence was at the age of 41-50, followed by $31-40$ and $23.6 \%$ of the cases was at the age above 50 .

The breast cancer patients with age of menarche at 12-15, were mostly found (see Table 7). The age range 
was similar to those who died with breast cancer in the 5 years observation. The highest mortality rate $18.8 \%$ ( 20 cases) was also seen in women with regular menstrual cycle and $20.9 \%$ (23 cases) in the menopause patients. Among 110 female cases who were analyzed on this score only $6(5.4 \%)$ were unmarried. The rate of married women in our population was high, except for the highly educated and professional class, the unmarried patients were an exception. Relationship between breast cancer and parity is also shown in Table 7 . Only $10(9,09 \%)$ patients were nulliparous. There was no defined relationship with parity. Maximum number of cases occurred in women with 2 or 5 children. In most of the cases, history of breast feeding was available. Age of first pregnancy could be more important than number of pregnancy or duration of lactation. It was also found that $43(39 \%)$ patients had a history of cancer in the family and $67(69 \%)$ patients had no history of cancer in the family. During the period of 1989-1992, 110 cases were treated by surgery, radiation and chemotherapy on the clinical evidence of regional metastasis. Histopathological features were analyzed according to the histological classification of Japanese Breast Cancer Society (1984). The commonest cancer in this group was the carcinoma ductal invasive (papillotubular type) and carcinoma ductal invasive schirrhous type. Adenoid cystic carcinoma, mucoid carcinoma and Paget Carcinoma were found as rare varieties. The distribution of cases with different histological types in relation to their survival status are given in Table 8. The results of 5 years follow up on patients survival are given in Table 9.

Table 8. Histological classification of breast tumors (Japanese Breast Cancer Society, 1984)

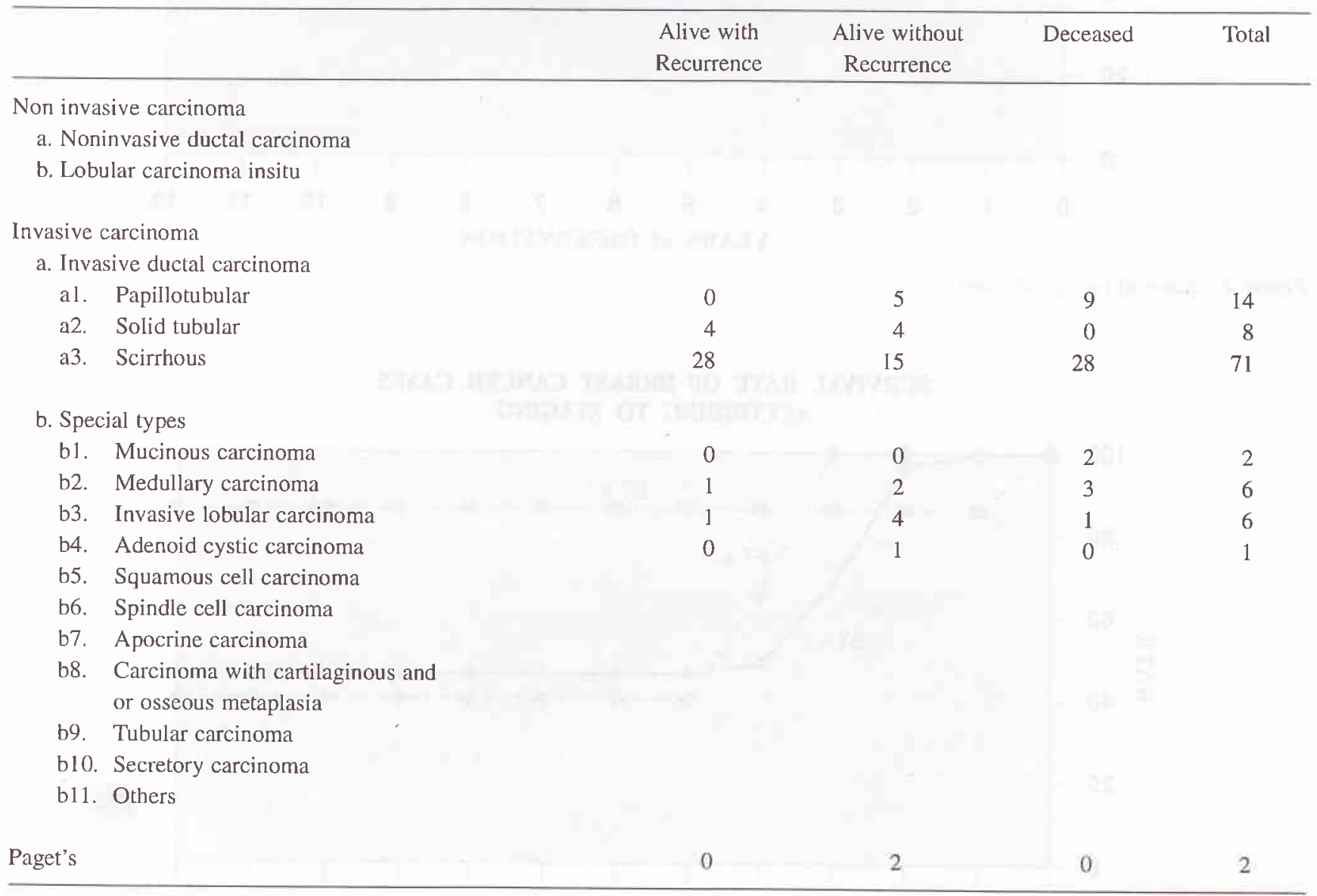


Table 9. Follow up status of 110 operable breast cancer patients in Dr. Cipto Mangunkusumo Hospital until 1995

\begin{tabular}{lcc}
\hline \multicolumn{1}{c}{ Follow up status } & Cases & $\%$ \\
\hline Still alive withhout recurrence & 33 & 30 \\
Still alive with recurrence & 34 & 31 \\
Deceased & 43 & 39 \\
\hline Total & 110 & 100 \\
\hline
\end{tabular}

Figures 1 and 2 depict the survival curve for all cases and for different clinical stages respectively. Patients with stage I showed relatively high survival (over $80 \%$ ), which level off until 5 years observation and further estimated in the Kaplan-Meier procedure. $\mathrm{Pa}$ tients with stage II and III showed a decline in survival rate since the $2^{\text {nd }}$ and the $3^{\text {rd }}$ year observation respectively and drop to around $40 \%$ at 4 and 5 years observation respectively. The latter was estimated further to level off.

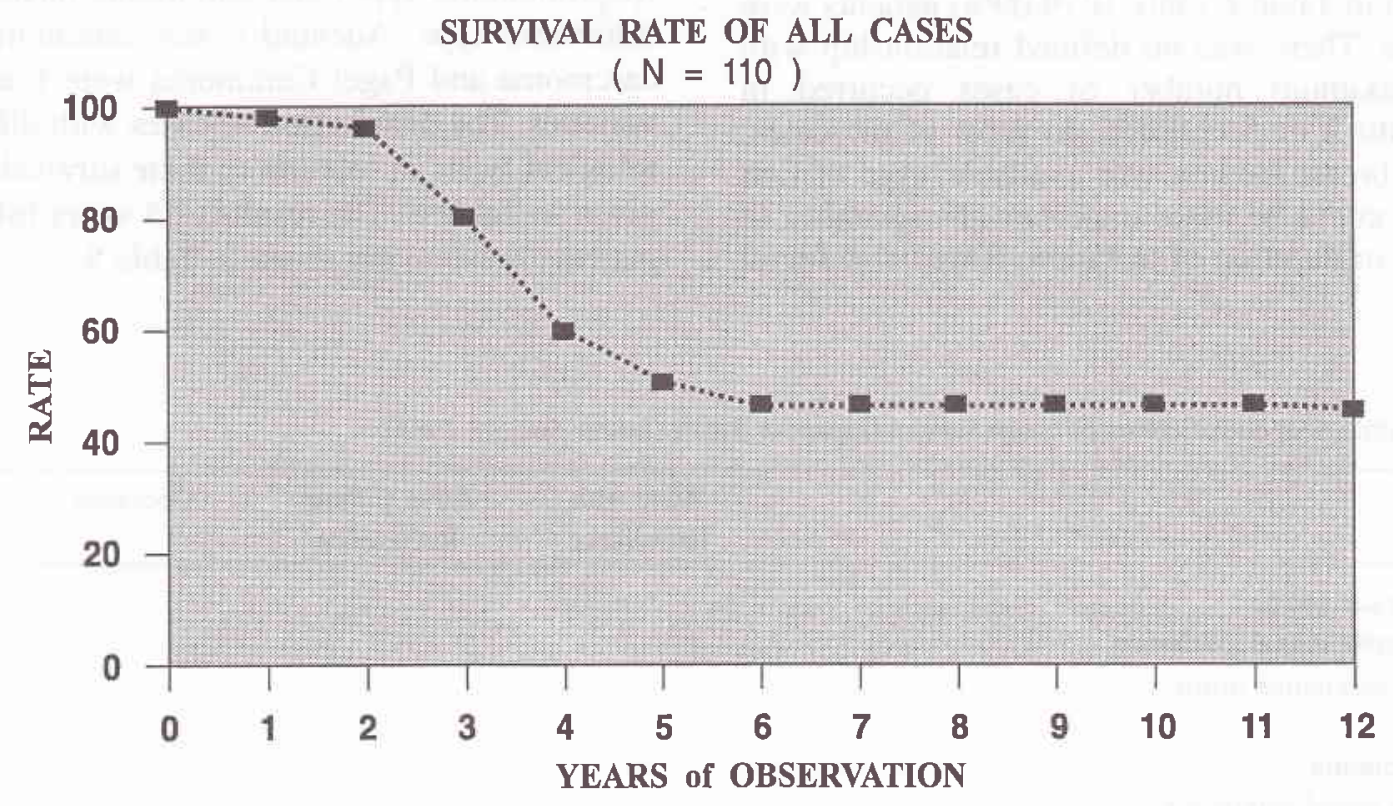

Figure 1. Survival rate of all cases

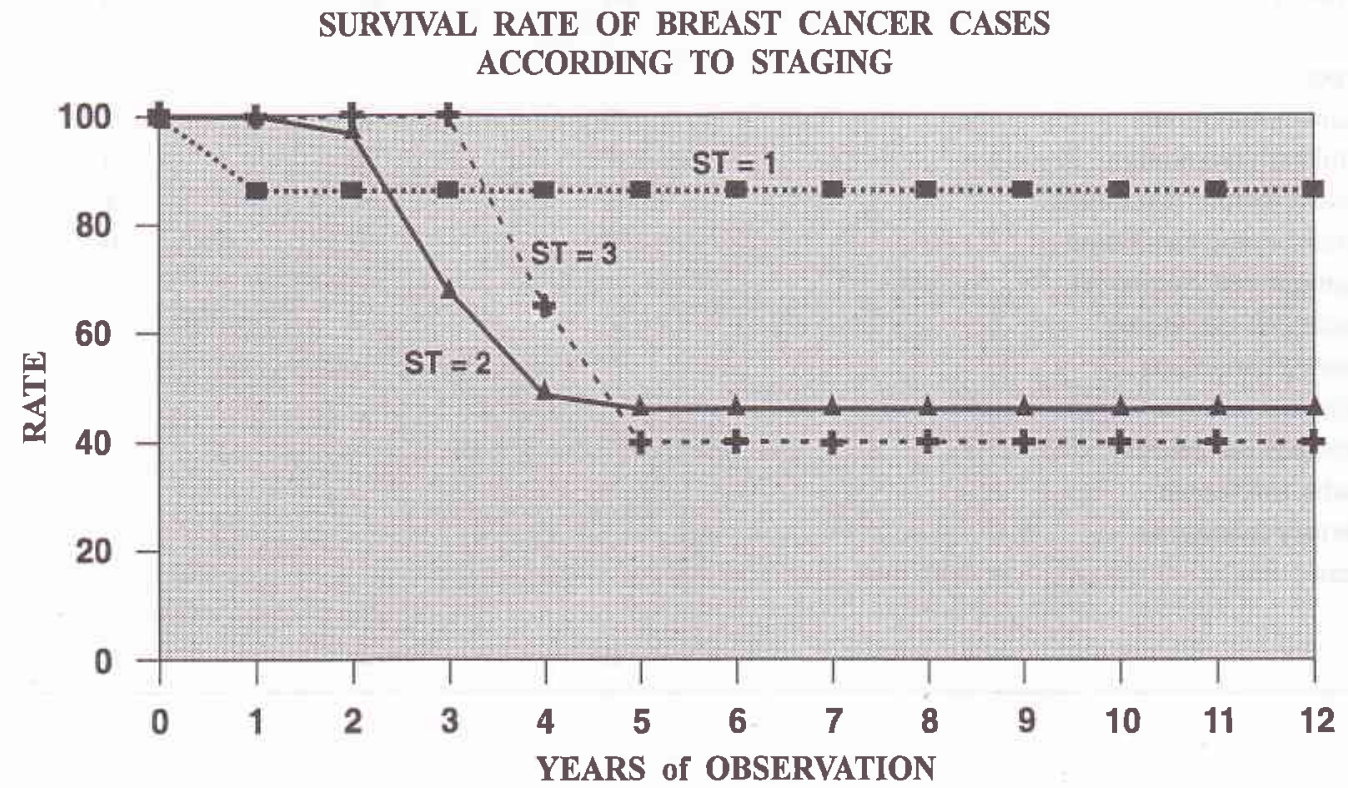

Figure 2. Survival rate in different stages $(I, I I, I I I)$ 


\section{DISCUSSION}

The results of three fold studies, i.e. clinical pathological and epidemiological aspects of 300 cases of Indonesian females breast cancer have been reported. 10,11 Various risk factors which have been investigated by others, including some demographic characteristics, reproductive status, external exposures and dietary habit. $12-14$ However, longitudinal follow up evaluating the clinicopathological data and epidemiological data in relation to survival data was rarely reported.

During the 5 years survival observation of the $1^{\text {st }}$ batch (110 operable breast cancer patients), we found that the results of treatment showed a diminishing survival after more advanced stages. The proportion of survivors were $87.5 \%$ in stage I, $61.3 \%$ in stage II and $57.8 \%$ in stage III. It can be seen that the extend of the disease or the clinical stages at the time of initial treatment is the most important factor in determining the result of treatment. ${ }^{15-18}$ Our own results also demonstrate this fact. Since 1989, 110 breast cancer cases had been followed up and the result showed that $35(30 \%)$ patients were alive without recurrence, $34(31 \%)$ patients were alive but with recurrence or metastatic disease and 43 (39\%) patients died during the follow up.

It is of interest that the disease free interval had relation to the stage of disease as shown in Table 7. Details of the 8 patients with stage I were $7(87.5 \%)$ still alive without recurrence and $1(0.9 \%)$ died of a heart attack. Among 31 patients with stage II $13(41.9 \%)$ were at present disease free (the longest disease free period in this group became 5 years) and $6(19.3 \%)$ had developed recurrent disease within 4 years or less. While for stage IIIA, out of 71 patients, 13 patients (18.3\%) were at present disease free and 28 patients $(39.4 \%)$ had developed recurrent or metastatic disease within 4 years or less. We also analyzed the age of incidence, hormonal status, parity and family history of breast cancer in relation to breast cancer. The findings revealed that most of our breast cancer patients were at the age of 3549 , younger than Western women with mean of age of 53.8 , and similar to that of Japanese women. ${ }^{19-20}$ Similar findings were also seen in other geographical area of our country with rather different demographical composition i.e. East Java. ${ }^{21}$

Malignancy in breast cancer patients was highly found in 20 patients with regular menstrual cycle (35.0\%) and in 23 post-menopause patients $(53.4 \%)$. Those with irregular menstrual cycle were still pres- ently alive. This result matched the study performed in 1979 to 1983 , which was followed up until 1988.22 In this study the 5 years survival observation of 121 breast cancer patients with irregular menstruation showed a better condition than those with regular menstrual cycle and in the menopausal status.

However according to my second study of the tenyear survival observation in Jakarta, from the some sample (1979 to 1981) and continued until 1991 the menopausal group have a better survival than those with the regular and irregular menstrual cycle. 23

Nulliparous women were considered more susceptible to breast cancer ${ }^{24}$ but our observations showed that 2 or more parous women had higher incidence of malignancy of breast cancer than less parous women. However, the age of first pregnancy had been found to correlate with incidence universally. In our study, only 43 patients (39\%) out of 110 had a history of cancer in the family. This probably had some correlation to the educational status. Since most of our patients came from the lower socio-economic status, they may not tell their family disease accurately.

Concerning the pathohistological features almost all breast cancer arises from ductal epithelium. Although some also arise from gland lobules. Our over all fiveyears survival observation resulting in $68.8 \%$ survival rate does not show significant difference in comparison with the observation of other authors from the Western World.25-26 According to Nealon et.al. the overall mean 5 years disease free survival (NED) for all patients (185) undergoing operation in each year changed remarkably little over the entire period. The mean disease free survival of all cases was 65 percent. The mean disease free 5 year survival of T1 No Mo tumor was $76 \%$ the mean disease free 5 year survival for T2 No Mo lesions was $68 \% .27$ Ile et. al. at the Curie Foundation Paris found in 1978 an absolute 5 year survival on 394 patients, 85 percent and 75 percent at 10 years. ${ }^{25}$ Crile, S. Jr. found the fiveyear survival rate in 143 collected cases were $79 \%$ for those without metastasis. 26

In order to obtain better estimate of the survival rate, the total of operable breast cancer patient has to be increased until approximately 200-300 patients. In addition, we are aware that related studies such a hormonal receptors (ER and PR) and oncogenes (C-er B2 and P53) are important tools to predict the influence of the tumor growth, response of therapy as well as the prognostic of the expectancy of life. ${ }^{27-29}$ 


\section{Acknowledgments}

The authors are grateful for the nurses Mrs. Emmy, Mrs. Ros and for the Public Health nurses Mrs. July and Mrs. Erlaini also for Dr. Sonar Panigoro and the staff of the Surgical Oncology Division, Department of Surgery Faculty of Medicine University of Indonesia for their excellent care and collection of data on breast cancer cases and control.

We are also indebted to the laboratory technicians for their excellent work on Surgico Pathological speciment. This work was supported by the Ministry of Education, Science, Sports and Culture of Japanese Government, grants No. 01042007, 044042013, 06042006 and was partly supported by the Indonesian Cancer Foundation. This collaborative study also was a part of special Cancer Research Project in Monbusho International Scientific Research Program with the approval from the Dean, Faculty of Medicine University of Indonesia No. 4383/PT02.H4.FK/ A88.

\section{REFERENCES}

1. Baum M. Breast Cancer: The Facts, Oxford University Press, 1981

2. Cornain S, Mangunkusumo R, Nasar IM, Prihartono J. Ten Most Frequent Cancers in Indonesia: Pathology Based Cancer Registry Data of 1988-1992. In: Cancer Registry in Indonesia. National Cancer Registry Centre, Jakarta Co-ordinating Board, 1997

3. Sarjadi. Cancer Incidence 1985-1989 in Semarang, Indonesia. Indonesian Cancer Foundation 1990

4. Stanley K, Stjersward J, Koroltchouk V. Women and cancer. World Health Statistic Quart., 1987; 40: 267-78.

5. WHO, IARC. Cancer Incidence in Five Continents. IARC, Science Public No. 15, Vol. III Lyon 1976

6. Muller CB, Jeffries W. Cancer of the breast carcinoma among American and Japanese women. In: McGuire WL, editor, Breast Cancer. Nashville: Plenum Publishing Corp., 1991; 18: S81-3

7. Japanese Breast Cancer Society. The general rules for clinical and pathological recording of breast cancer. Jpn J Surg 1989; 19: $612-32$

8. TNM Atlas illustrated guide to the TNM/P TNM Classification of Malignant Tumors. $3^{\text {rd }}$. Berlin: UICC Springer Verlag, 1990: $173-83$

9. Rimm AA, Hartz AJ. Kalbfleisch JH, Anderson AJ, Hoffman RG. Basic Biostatistic in Medicine and Epidemiology. Appleton Century Crofts, New York, 1980

10. Cornain S, Ohno Y. Progress Report, Japan-Indonesia Joint Study on Etiology and Clinicopathology of Breast Cancer, Jakarta: School of Medicine University of Indonesia, 1992, May.

11. Budiningsih S, Ohno Y, Prihartono M, Ramli M, Wakai K, Cornain S, et al. Epidemiological Analysis of risk Factors for
Breast Cancer. In Indonesian females. Med J Indones 1995; 4: $163-8$

12. Vadya MOP, Shukla S. A textbook of breast cancer. New Delhi: Vikas Publisher, Home PVT Ltd, 1983: 54-67

13. Ohno Y. Methodology and evaluation of dietary factors in Japan In: Mettline CJ, Aoki K, editors. Recent Progress on Nutrition of Cancer. New York: Wileyliss Inc. 1990: 11-20

14. Van T, Veer P, Kok J, Brants HAM. Dietary fat and the risk of breast cancer. Int J Epid 1990; 19: 15-7

15. De Vita VT, Heelman S, Rosenberg SA. Cancer Principles \& Practice of Oncology. Philadelphia: J.B. Lippincott Co., 1982: 982

16. Haagensen CD. Diseases of the Breast. Philadelphia: W.B. Saunders. $2^{\text {nd }}$ ed. 1971: $348-54$

17. Donegan WL, Spratt JS. Cancer of the Breast, Philadelphia: W.B. Saunders, 1979: 15-43

18. Tjindarbumi D. Early Detection of Breast Cancer (In Indonesian). Annual Scientific Meeting of Indonesian Surgeon Associations, Jakarta, 1982

19. Sakamoto G, Sugano H. Pathology of breast cancer: Present and prospect in Japan. Breast Cancer Res and Treatment 1991; 18: S81-3

20. Sakamoto G, Sugano H, Hartman WH. Comparative pathological study of breast carcinoma among American and Japanese women. In: McGuire WL, editor. Breast Cancer. Nashville: Plenum Publishing Corp., 1981: 21: 1-31

21. Sukardja I.D.G. Early Detection of Breast Cancer in East Java, Impact of Public Education on Cancer. A Longitudinal Study PhD Thesis. Surabaya: Faculty of Medicine, Airlangga University, 12 July, 1984

22. Tjindarbumi D, Badri $\mathrm{CH}$, Tjahjadi G: Five-year survival rate of operable breast cancer in Jakarta, Indonesia. Indones J Oncol 1990; 2: 1-23

23. Tjindarbumi D. Management and results of operable breast cancer in several hospitals in Jakarta: A Ten-year survival rate observation. Indones J Oncol 1991; 2: 147-60

24. MacMahon B, Cole P, and Brown J. Etiology of human breast cancer: A review JNCI 1973; 50: 21

25. Nealon TF Jr. Management of the Patients with Cancer, IIIrd Educ. W.B. Saunders Co., Philadelphia: 1986, 186-93

26. Crile S. Results of simple mastectomy without irradiation in the treatment of operative stage I cancer of the breast. Annals of Surgeon 1968; 168: 330

27. McTierman A, Thomas DB, Johnson LK, Rossman D. Risk factors for estrogen receptor-rich and estrogen-poor breast cancers. JNCI 1986; 77: 849-54

28. Iwaya $K$, Tsuda $H$, Hiraide $H$, Tamaki $K$, Tamakuma S, Fukutomi T, et al. Nuclear p53 immunoreaction associated with poor prognosis of breast cancer. Jpn J Cancer Res 1991; 82: $835-40$

29. Takikawa $Y$, Noguchi $M$, Kitagawa $H$, Thomas $M$. Immunohistochemical detection of $\mathrm{p} 53$ and c-erbB-2 proteins: Prognostic significance in operable breast cancer. Breast Cancer 1994; 1: 17-23 